\title{
2. UPGRADING OF. AMP SOCIETY BRANCH OFFICE CORNER CUSTOMHOUSE QUAY AND HUNTER STREET, WELLINGTON
}

\author{
M.C. Cathie* and J.M. Leuchars**
}

\section{BRIEF DESCRIPTION OF ORIGINAL BUILDING:}

This commercial building constructed in 1925, comprises a basement, ground, mezzanine and six upper floors with a small penthouse over. It has a plan area of approximately $1400 \mathrm{~m}^{2}$.

The structure consists of reinforced concrete floors supported on a riveted structural steel frame. The frame has main girders and columns arranged in the north-south direction and secondary

framing at right angles, the whole being encased in reinforced concrete.

The columns spring at their bases from steel grillage foundation pads, supported directly on solid base greywacke at a depth of 3-4 m below ground level.

On the street frontages (east and south elevations) the primary frame is infilled with a system of reinforced concrete spandrels and piers all finished externally with sandstone and terra cotta facings.

On the north and west elevations the perimeter steel frames are largely infilled with solid reinforced concrete. A service core, situated centrally toward the eastern end of the building, is like constructed.

Two lightwells were provided within the site, one in the north-western corner and the other situated centrally within the building.

\section{SPECIFIC PROBLEMS:}

The design and construction of the existing building was of top quality for its era, however the building had poor overall torsional characteristics which amplified the seismic attack on the masonry facades. The new seismic resistant components had to be sufficiently stiff to limit induced loads on the facade system. This led to the selection of large stiff shear walls distributed around the structure but located where there was no reduction in facade openings or obstruction of the internal spaces.

The engineering and architectural work had to be detailed so that the client could occupy all but two floors and basement at any time. As floors were handed back for occupation all building services and egresses had to be functional.

*Associate, Smith Leuchars Ltd

**Director, Smith Leuchars Ltd
The constraints of having all contractors work sandwiched in to two floors between the tenanted floors; a construction programme limited to 18 months, on a refurbishment project far larger than any previously attempted in New Zealand, ensured that the project would test all involved to the limit.

\section{DESIGN STANDARDS:}

$\begin{array}{ll}\text { Loadings } & \text { NZS 4203:1976 } \\ \text { Concrete } & \text { DZ 3101 } \\ \text { Structural Steel } & \text { AS 1250:1981 / } \\ & \text { NZS 3404:1977 }\end{array}$

\section{SOLUTIONS ADOPTED:}

The overall lateral force resisting system adopted for the building was a series of five reinforced concrete shear walls, two oriented North-South and three lining East-West. This system provides an adequate stiffness to prevent major damage to the facade stonework and suited fire rating requirements for boundary walls to the western lightwell infill extension.

Wall I, was poured against the South reinforced concrete wall of the existing main lift core. It was designed and detailed as a ductile coupled shear wall (necessary due to the existance of centrally located egress openings at levels above Ground Floor), extended to the underside of Level 6 and was dowelled into the existing wall with epoxied reinforcing bars at centres required to develop the capacity of existing reinforcing and structural steel. A new pad foundation, excavated to greywacke level, augmented the existing concrete encased steel grillage foundation at the East end of the wall, whilst the existing grillage foundation was found to be adequate at the West end. Permanent ground anchors, drilled through existing foundations provide resistance to overtuning.

Wall 2, constructed in similar manner to Wall 1, against the West wall of the existing lift core, was designed as a ductile centilever shear wall and again utilised the capacity of the existing concrete wall. Existing foundations were utilised in combination with new ground anchors. The wall extends to the underside of Level 5.

Wall 3, was dowelled into and poured against the exterior face of the existing North-East boundary wall. It was designed and detailed for limited ductility and utilised existing wall strength and foundations.

Wall 4, was a combination of reinforced sprayed concrete dowelled to existing 
masonry infill walls (tied also to the supporting frame) and new in-situ wall over the lightwell infill section. It was designed and detailed for limited ductility and utilises existing foundations at the East end and a new foundation at the West end. The wall against the existing structure extends to Level 3 while the new portion of the wall extends to lift machine room level.

Wall 5, extends full height of the building and was constructed in-situ. It was designed for limited ductility and is founded on pads tied down for overturning moments with permanent ground anchors.

Existing reinforced concrete floors, combined with new Dycore infill floors (75mm topping) at the old lightwell locations, provide horizontal diaphragms at all levels.

The reinforced concrete backed facade stonework spandrels are positively tied back internally to existing structural steel columns with horizontal structural steel whalers at window sill level. The spandrel is bolted to the whaler with resin capsule anchors. The whaler, in turn, is welded to the existing columns.

The central lightwell infill floors are carried by reinforced concrete gravity frames to first floor level, whereupon existing pairs of concrete encased structural steel columns carry loads to existing foundations.

\section{PARTICULAR CONSTRUCTION ASPECTS:}

The installation of ground anchors proved to be a major programing constraint in extending the structure above given the tight work schedule. This was overcome by leaving the end sections of wall unpoured at basement level and continuing with the full wall width above. These end wall sections were later completed as drilling and stressing of ground anchors progressed.

Because of similar programming constraints in the construction of new Wall 5, brought about by the amount of associated ground excavation necessary to foundation level, the wall above ground floor level was constructed on temporary structural steel columns, which were later encased within the wall below the ground floor.

All heavy demolition and drilling work was restricted to outside normal working hours.

\section{COST BREAKDOWN:}

Costs for the refurbished building included a $23 \%$ increase of floor area provided, a new goods/passenger lift, full air conditioning, new suspended ceilings, floor and wall finishes, completely new electrical, mechanical and PABX systems and a basement carpark. The total value of work undertaken was approximately $90 \%$ of new building cost of equivalent area. By strengthening and extending the existing building a far higher plot ratio was achieved than mat was allowable for a new building. section:

$$
\text { The costs breakdown to the following }
$$

$\begin{array}{ll}\text { Structural } & 30 \% \\ \text { Mechanical/Electrical } & 39 \% \\ \text { Architectural } & 31 \%\end{array}$

COMMENT SUMMARY:

Detailing for strengthening of a structure given the constraints of architectural planning and an owner who desires to remain in occupation during construction is a difficult exercise in both the planning and construction phases. Problems arising were overcome with the co-operation of all parties involved in design and construction of this architecturally historical building, strengthened to full modern code level.

Current Owner: Australian Mutual Provident Society

Principal Consultant

and Structural

Engineer:

Smith Leuchars Ltd

Services Engineer: Sanders Johnson Smith Itd Architect: Pedale Thorp and Maidens Quantity Surveyor: Knapman Clark and Co.

Contractor: Fletcher Development and Construction Co. Ltd

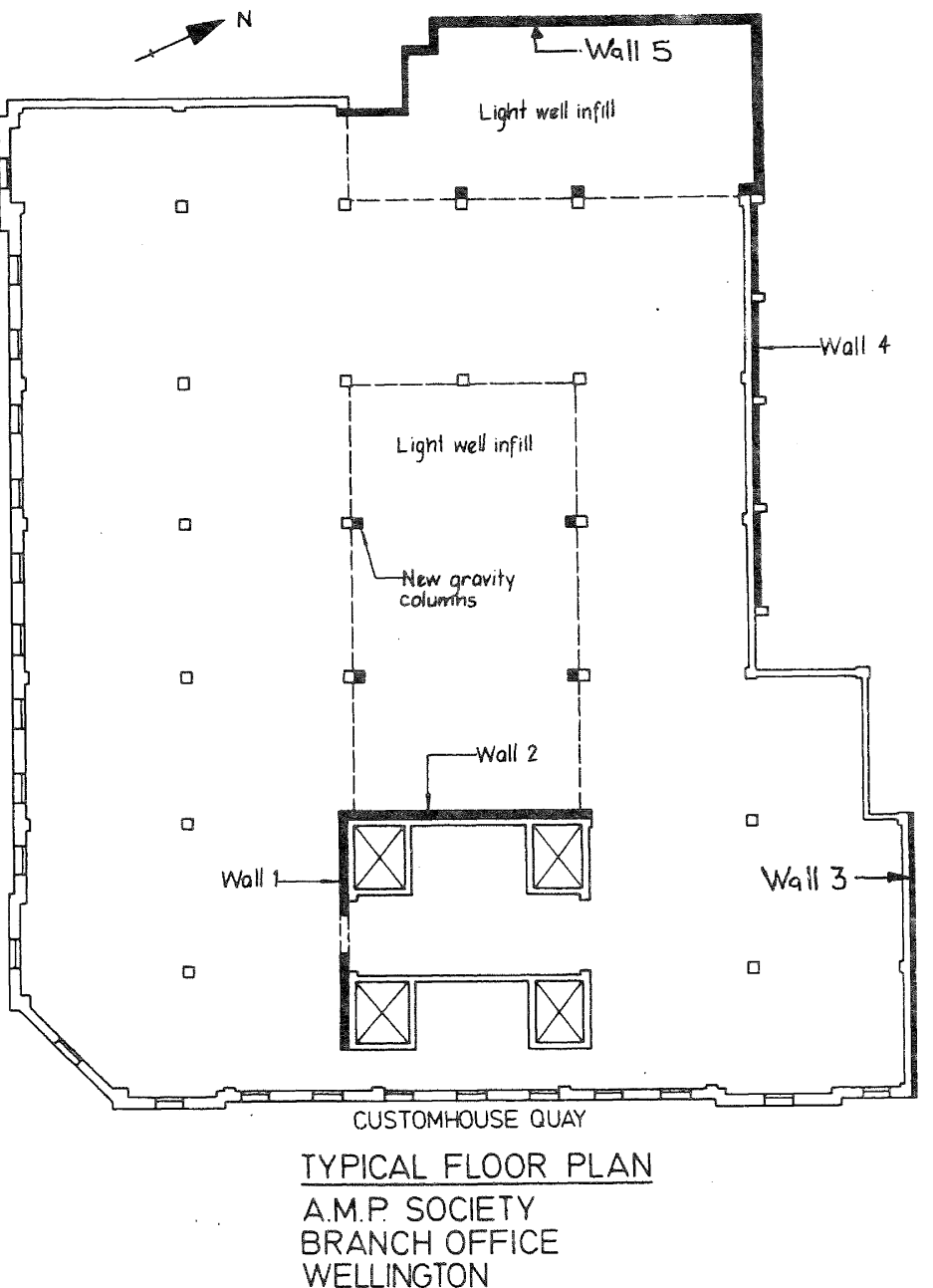

